2000

\title{
A Grand Exercise in Forgiveness, or Justice Held Hostage to Truth? South Africa's Truth and Reconciliation Commission
}

Penelope Andrews

New York Law School, penelope.andrews@nyls.edu

Follow this and additional works at: https://digitalcommons.nyls.edu/fac_articles_chapters

Part of the Human Rights Law Commons, and the International Law Commons

\section{Recommended Citation}

Andrews, Penelope, "A Grand Exercise in Forgiveness, or Justice Held Hostage to Truth? South Africa's Truth and Reconciliation Commission" (2000). Articles \& Chapters. 1230.

https://digitalcommons.nyls.edu/fac_articles_chapters/1230 


\title{
Book Review
}

[2000] Melbourne University Law Review 8

\section{A Grand Exercise In Forgiveness, Or Justice Held Hostage To Truth? South Africa'S Truth And Reconciliation Commission}

\author{
Judging the Judges, Judging Ourselves: Truth, Reconciliation and the Apartheid \\ Legal Order by David Dyzenhaus
}

(Oxford: Hart Publishing, 1998) pages i-xviii, 1-206. Price $£ 22.50$ (hardcover). ISBN

1901362949.

What kind of world was this? In the existential belly of white supremacy, ordinary human relations were suppressed or distorted. The normal likes and dislikes of people for one another were controlled by the state and disfigured by white supremacist culture; the whole ugly process was hidden behind the soothing euphemisms of apartheid, or separate freedoms. It was a world that was upside-down.[1]

This vivid description of one of the 20th century's most shameful epochs, the 'upside-down' nature of this world, indicates why South Africans appreciated that the shift from a society premised on apartheid to one characterised by democratic notions was never going to be easy. Both in the formal arrangement negotiated to transform the society and thereby produce the new Constitution,[2] as well as in the myriad of informal interactions occurring daily, urgency and compromise loomed large. In other words, between February 1990 (the date President Mandela was released from prison) and May 1994 (the date of the first election) South Africans were immersed in the business of planning and shaping the new democratic order. These few years were also a particularly violent period.[3]

The constitutional arrangement agreed to has generally been hailed as one of the century's most impressive.[4] The Bill of Rights is expansive in its coverage of a plethora of protected individuals and groups, its generous definition of equality and the impressive list of bodies mandated to enforce the rights enumerated.[5] The Constitution is a model of compromise: it incorporates and embraces the demands of various lobbying groups who wanted to ensure that their needs and interests were accommodated in the final document.

Although the drafters of the Constitution ensured that it embraced the vision of the new South Africa, they realised they had to confront the human rights abuses typified by apartheid which had left an indelible mark on the society, and which had spawned numerous victims. It was generally believed that the transition to democracy and stability could only be achieved if the unfinished business of apartheid was dealt with. In short, the task was to face the monster of 
apartheid (represented by an unaccountable security force) and eliminate its destructive potential forever.

The instrument which was agreed to as the best means of accomplishing this task was the Truth and Reconciliation Commission ('TRC'). The TRC was set up to advance the goals of reconciliation and reconstruction in South Africa, furthering the imperatives set out in the first post-apartheid Constitution. [6] The architects of the TRC saw that its purpose would not be merely to make reparations to victims, but would also be to lead to institutional reform. They saw that its role would be to contribute to the values of the institutions of the new democratic order. The TRC was seen as one of the foundational institutions in South Africa (some would argue the main institution) to bridge

the past of a deeply divided society characterised by strife, conflict, untold suffering and injustice, and a future founded on the recognition of human rights, democracy and peaceful coexistence and development opportunities for all South Africans, irrespective of colour, race, class, belief or sex.[7]

Most significantly, the TRC articulated its purpose as being to explore the relationship between truth and justice.

The TRC represents an impressive model of political compromise, its existence seen as crucial to the new democratic order. The TRC has been viewed as having the potential to make a uniquely important contribution to democratisation and development in South Africa, that is, helping to strengthen the (moral) basis of an emerging democracy.

South Africa's TRC drew much on other models of truth commissions, especially those from Latin American countries, [8] but settled in favour of a more extensive mandate. For example, the South African Parliament rejected the notion of blanket amnesty in favour of individual amnesty on application so that the truth could be excavated unconditionally. What is particularly unique about the South African model, however, is that its parliamentary mandate included not only an investigation into the gross violation of human rights, that is, a thorough investigation of the deaths and disappearances of activists, but also an interrogation of the organisations and institutions of civil society that advanced the cause of apartheid, or benefited in some way from it. The media, medical establishment, legal profession, churches and the business community all fell within the ambit of the TRC as it pursued its mandate. The TRC focused not only on the dark deeds of individual perpetrators, but also on highlighting the responsibility of various institutions for injustices in the form of gross human rights violations, which had resulted from their acts of commission and omission. Chains of command were investigated, submissions were requested from groupings, and hearings and investigations were accompanied by a consultative process of preparing detailed recommendations to prevent violations in the future.[9]

Another significant feature of the TRC in South Africa was its mandate to investigate all sources of human rights violations. This was in recognition of the uncomfortable fact that the perpetrators of human rights violations did not just emanate from one origin, but included members of the police and security forces serving the National Party (the official party of apartheid) as well as members of Umkhonto We Sizwe, the liberation army of the African 
National Congress ('ANC'), the Azanian People's Liberation Army and the Inkatha Freedom Party. The issue of moral parity, that is, between those imposing apartheid and those fighting it, has generated some debate.[10]

The TRC was divided into three committees. The Committee on Human Rights Violations was entrusted with the task of designating victim status to individuals as articulated in the enabling statute, for the purposes of reparations and rehabilitation. The Committee for Amnesty was empowered to grant amnesty to individual perpetrators after 'full disclosure of all relevant facts' for acts associated with political objectives,[11] thereby shielding such perpetrators from criminal and civil liability. The question of amnesty generated some opposition from the families of victims, culminating in an unsuccessful court challenge to the constitutionality of the TRC.[12] The Committee on Reparations had the task of submitting a report to the South African Government to inform the latter's approach to reparations and rehabilitation of victims.

The notion of who is a 'victim' of apartheid is a complicated one, since arguably everybody who was subjected to its deleterious impact suffered. In other words, the 'ordinary' victims of apartheid, those individuals denied education, housing, jobs and other basic needs because of their race, are victims of apartheid, and arguably ought to be compensated in some way.[13] However, the process of the TRC, and its targeting of victims of gross violations of human rights, set apart the extraordinary victims of apartheid. This is overall a good thing, because not every black person[14] could certainly be compensated. Recognising gross violations of human rights under apartheid does not absolve the horror of its banality. By unmasking the horror of the excesses of the security apparatus, the ordinary system of apartheid, which buttressed white privilege, was implicated in this horror.

The proceedings of the TRC, and the way they unfolded between blacks and whites in South Africa, were in some ways inevitable. Many blacks felt vindicated that their prior knowledge of the excesses of the security establishment was now confirmed and had become part of official history. Most whites, on the other hand, witnessed the proceedings with sentiments ranging from indifference to outrage, the latter motivated by what they perceived as the ANC bias of the TRC, or a witch-hunt of Afrikaners.[15]

The choice of chairperson of the TRC, Archbishop Desmond Tutu, South Africa's second Nobel Laureate, infused a particularly evangelical, overwhelmingly Christian sentiment into the TRC's proceedings, and injected a particular model of reconciliation. Rituals of prayer, to commence the proceedings, or to intersperse awkward and troubling moments, became a staple.[16] Despite this, however, certain commentators believed the TRC to be more 'a source of division than of unity'.[17] From April 1996, when the TRC commenced its proceedings, until mid-1998, when the public hearings ceased, South Africans were transfixed at their radios and television sets as victims recalled dastardly tales of torture, disappearances and deaths, and the perpetrators attempted to disclose all. For a new democracy it was a tricky venture, one which could generate not ideas of reconciliation and forgiveness, but resentment and revenge.

In its endeavours, key questions had to be addressed by the TRC: What does reconciliation mean? Who should be reconciled? Who benefits from reconciliation? What are the benefits of 
reconciliation? The TRC was born out of an enormous sense of hope, but there was always the fear that it would degenerate into a quagmire of scepticism and cynicism.

An evaluation of the success or otherwise of the TRC may seem premature, but there have been some interesting reflections thus far. One such work is David Dyzenhaus' book, Judging the Judges, Judging Ourselves: Truth, Reconciliation and the Apartheid Legal Order.[18] The book is a narrative and critique of the legal hearings which took place over three days at the TRC. These hearings were the official inquiry into the legal order during the apartheid era and into those who sustained the system, in other words, those who made it possible and workable, and gave it credibility.[19]

The purpose of the legal hearings differed somewhat from those of the individual victim and perpetrator inquiries. The former were to serve as an inquiry into the legal system, without recourse to confrontation and condemnation. Dyzenhaus doubts whether they succeeded, claiming that ' $[\mathrm{t}]$ he atmosphere at the Hearing was more often than not confrontational and accusatory, more like a trial than an inquiry.'[20] Judges were berated not just for dereliction of their legal and moral duties under apartheid, but also for failing to appear before the TRC to provide a comprehensive account.[21]

The legal hearings were arguably the most crucial of the institutional hearings. After all, it was the processes of law which kept apartheid in place. It was the formal legal edifice, one not too distinct from its European counterparts, which gave apartheid its respectable face.[22] The apartheid government, unlike its counterparts in Central America during the 1980s,[23] was spared the necessity of relying on death squads and bands of paramilitaries to terrorise citizens into submission. Law regulated every aspect of people's lives, for example, where they could live, where they could go to school, whom they could marry.[24] It was a tightly woven institutional structure with its mandates and penalties, spectacular in its detail, and over most of the period of apartheid, administered without much public protest.[25]

The trappings of legality performed an important symbolic role for the minority white South African Government, allowing them the delusion that they were part of the Western democratic world. It also allowed the beneficiaries of apartheid, that is, white South Africans (as opposed to the perpetrators of gross human rights abuses), the benefit of reassuring themselves that they were living in a civilised state, regulated by law.[26]

Dyzenhaus sets out to describe the hearings as they took place, as well as to analyse their purpose and success. He outlines the positions taken by the main protagonists in the legal system - the judges, magistrates, lawyers, academics and public servants - and then sets out to analyse their roles during the apartheid era, and the substance of their submissions. The major focus of this study, as the book title suggests, is the role that judges played during the apartheid era and, by implication, their position within the new democratic order. In this endeavour he musters an impressive array of jurisprudential sources, and of course draws on his previous work.[27] The author also expands on his own submission to the TRC, coincidentally, the first to be made at the legal hearing. 
The author situates himself within the South African context as a white male who was conscripted to serve, and did serve, in the apartheid army, and is now an expatriate in Canada. $\mathrm{He}$ is a highly respected legal scholar who has written extensively on South African legal issues. From this vantage point he sets out to examine the legal hearings, and what light they bear on the past, the present and the future.

Dyzenhaus details a rather pathetic legacy on the part of the major actors in the legal system. From the members of the various bars, to the civil servants and academics, who all participated in this system of gross racial injustice, he illustrates a range of reactions from indifference and cowardice through to zealous promotion of the values of the Government. There is no doubt that despite the voices of some individuals in the profession, the professional associations of advocates and attorneys share a shameful history,[28] and Dyzenhaus chronicles this in some detail. His task is hampered somewhat by the paucity of submissions from the law schools and public servants, and by the guarded responses of the professional bodies representing attorneys and advocates.[29]

At the outset the author places himself at odds with one of South Africa's most eminent jurists, the President of the Constitutional Court, Arthur Chaskalson, who was also one of the most prominent anti-apartheid lawyers in the country. He refers to a speech made by Judge Chaskalson in 1989,[30] in which the latter referred to the possibilities of the application of the rule of law in a society characterised by fundamental legal inequality and burdened by the constraints of parliamentary sovereignty. In that speech Judge Chaskalson had referred to an 'almost schizophrenic approach' by the courts which were required to 'give effect to equitable common law principles' while at the same time upholding and enforcing 'discriminatory laws'.[31] Judge Chaskalson was of the view that judges were under a duty to resort to common law presumptions (of equality and liberty) when statutes were sufficiently ambiguous.[32] His position was premised on the Roman-Dutch and British common law principles on which South Africa's legal system was based.

Dyzenhaus differs from certain presumptions that Judge Chaskalson makes. He points to the immutable problem associated with parliamentary supremacy, namely, that statutory law always overrides the common law. The South African Parliament was therefore able either carefully to avoid common law presumptions, or to enact further legislation. He also disputes Judge Chaskalson's assumption that judges were under a duty to interpret the law in accordance with common law principles of equality and liberty. Dyzenhaus opines that the majority of South African judges adhered to the 'plain fact approach',[33] an interpretive methodology which seeks to give effect to the intention of the legislature, irrespective of common law principles or of the proclivities of individual judges. Dyzenhaus elicits significant examples which demonstrate the pattern.[34]

In their submissions, the liberal judges encapsulated their arguments as follows: there is no doubt that the judges lent credibility to this evil legal system, but their roles were crucial even though more often than not they paid lip service to the common law ideals of liberty and equality. They kept alive the idea of law and justice for people who very often had little else to turn to; that as limited and constrained as that possibility was, some victories may still have been possible. So for example, when trade unions started to organise and agitate for workers' rights and changes to 
the patently oppressive labour laws and policies, the courts were essential in advancing the cause of workers.[35] So too public interest lawyers, commencing in the late 1970s, began to challenge the most egregious aspects of apartheid in the courts. As apartheid's arrogance and confidence began to be challenged and began to wane, and as popular uprising loomed large, the courts became a significant site of political struggle. Victories were not always obtained, but they provided the possibility for vindication of rights.[36]

In the submissions of the liberal judges, it was also argued that the process of challenging state action in the courts had significant beneficial outcomes, two of which are relevant for the postapartheid era. The first is that the process kept alive the idea that the rule of law was important. In other words, the credibility of the courts, as contested a notion as it was, was important to sustain the ideals of the common law.[37] It is worth noting that even black lawyers, most sceptical of the legal system, and most disadvantaged by it professionally and personally, did not jettison the idea of utilising the law to fight injustice.[38]

The second idea is a practical one: the infrastructure of the legal system and all its accoutrements smoothed the way for the continuation of such an infrastructure; a not too insignificant factor in as fragile and nascent a democracy as South Africa.

Obviously, those judges who took an appointment despite their liberal leanings felt that they had room to manoeuvre and that the underpinnings of equity in the common law provided that space. But the process of co-option, even at a slow pace, posed a real impediment to such a possibility. And during the emergency period, the judges' ability to vindicate the rights of political opponents was sorely tested.[39]

Dyzenhaus states very stridently that more judges should have participated in the proceedings of the TRC.[40] But this position may not be as straightforward as it appears. For the sitting judges, as well as their retired colleagues, appearing before the TRC was a tricky business. The benefits of multiple meae culpae, that is, many individual and group submissions, may have had a salutary effect by adding to the perception that the judges who served during the apartheid years wanted to apologise and therefore contribute to the process of reconciliation. And in the short term, this may have been an overall good thing.

But there was a sentiment around that the downside of such an approach was considerable. South Africa's legal system had survived tremendous assaults on its credibility (assaults which were justified), and could boast at the installation of the new Government not just an impressive constitution and new constitutional court to enforce it, but a system of courts and a competent judiciary. Nevertheless, the system was fragile at the core. A nervousness existed about the loss of respect and credibility that may have accompanied large-scale judicial participation at the TRC hearing; this apprehension was not insignificant.[41]

Moreover, the hearings were too short.[42] Even if a quarter of the judges who served under apartheid made submissions with apologies, the time allocated to the hearings was not sufficient to fairly address the complexities attendant on this question.[43] 
Judge Chaskalson's exhortation that little was to be gained from lamenting the past in the light of all of this seemed perfectly reasonable. Dyzenhaus finds this proposition troubling, one that vitiates the purpose of the TRC. He takes Judge Chaskalson to task for advocating what he terms 'a politics of memory which opts for total or partial amnesia.' [44]

In the collision of memory and truth with certain unpalatable facts of legal history, interpretations of the rule of law may become hostage. Dyzenhaus sees this as the core of Judge Chaskalson's 'nothing to be gained from lamenting the past' posture, one shared by a liberal former Chief Justice, Judge Corbett, and other judges. In other words, Dyzenhaus wants the past to be critically unbundled, with some limitations, in a way that implicates interpretations of the rule of law as explicitly political:

Just as remembering the past will reveal the politics of the different understandings of the rule of law, so a policy of forgetting the past (however noble its motivation) will obscure such politics, perhaps permitting the bad old politics to exercise a hold on the future.[45]

Dyzenhaus unearths an old debate in South Africa, one sparked by a law professor, Raymond Wacks, who argued in a lecture in 1983 that liberal judges ought to resign because they served to legitimate a highly oppressive legal order.[46] His detractors were liberal academics who believed that, even within the severe constraints of parliamentary sovereignty, the benefits derived from judges remaining on the bench outweighed the possible benefits (the political and moral statement) that may have flown from their resignation.[47] This debate, intense for a brief period, fizzled out because Raymond Wacks' call was not popularly supported, and in any event, after a very short tenure at the University of Natal, he moved to the University of Hong Kong.[48]

While Dyzenhaus agrees with Wacks that liberal judges add legitimacy to the legal system, he does not think that calling for their resignation was good counsel. He disagrees with the premise of Wacks' position, namely that judges had no interpretive flexibility. At times judges could provide a judgment, even with a statute clearly violating rights, that gave a victim some relief in the courts.[49] Dyzenhaus also agrees that the resignation of liberal judges would impact negatively on the future and the prospects of ensuring respect for the rule of law.

Dyzenhaus' book is a thoughtful account of the legal hearings and the issues they raise. He deals with the complexity of truth and memory, with contrasting interpretations of the past and their articulation in contemporary South Africa. It is a difficult project, because that process of truth and memory (and reconciliation) is still a work in progress, far from any resolution. In fact, there really is no resolution: only questions raised and appropriate interpretations and responses given.

Dyzenhaus makes an excellent point about the role of the legal hearings in forcing the connection between the ordinary and extraordinary violence of apartheid:

By examining together the administration of statutes which set out the programme of apartheid and the statutes which set up the framework for suppressing opposition to apartheid, the Hearing revealed the continuum between ordinary and extraordinary violence.[50] 
The author's major focus on the judges is not unproblematic. Judges were not the major legal players during the apartheid era, although obviously they were not insignificant. Their tasks included a review of all decisions from the lower courts. But they exist in a rather arcane world. The interface of the brutalities of apartheid occurred for most black South Africans in the myriad of lower courts, particularly the magistrates' courts and the then Black Commissioner's courts.

Of particular relevance were the horrors inflicted by the ubiquitous 'pass courts' which rendered life frighteningly insecure for millions of Africans over the entire period of apartheid. The pass courts enforced the system of influx control, a system which regulated the movement of Africans in the most Kafkaesque manner, and arguably was the linchpin of apartheid.[51] Africans were only allowed in the urban centres of South Africa to provide their labour, and permission was only granted under the most stringent, and often arbitrary, conditions. This is where the majority of South Africans experienced apartheid at its crudest and most cruel.[52]

The commissioners who adjudicated matters in the pass courts were mostly career civil servants with the most rudimentary legal training. They were mostly Afrikaners and their ideology coincided with that of the ruling National Party. It is not too implausible to say that they did not wrestle with difficult moral and philosophical questions in their tasks. Judges, on the other hand came from a more elite group of people. They were more educated, were almost overwhelmingly drawn from the ranks of advocates and were not overwhelmingly Afrikaner.

Dyzenhaus recognises that his focus on judges may appear somewhat distorted, but argues that it is 'both inevitable and productive', an argument he substantiates by referring to the work of Robert Cover, an American law professor, and his impressive study of judges of the antebellum period in the American South. 53] Cover's work attempts to deconstruct the intrinsic relationship between law and justice.[54] In other words, if one accepts that law embodies within it the ability to achieve justice, then the adjudication of the law by judges is key to that analysis. And since Judge Chaskalson and Archbishop Tutu adhere to that position, evaluating the role of judges at the TRC hearings 'provided a rare opportunity to reexamine the relationship between law and justice.'[55]

The mechanics of stage-managing the process of truth and reconciliation are complicated and difficult, especially as the process involves unfolding a shameful past and shaping the present and the future. The legal system in South Africa, simultaneously hardy and vulnerable today, has been at the centre of the transition. In fact, most commentators see the revolution there as largely a legal one.[56] There is no doubt that since 1994, major institutional reforms of the legal system have occurred, symbolised by the presence of the two most prominent jurists in the country, Judge Chaskalson, President of the Constitutional Court, and Judge Mahomed, Chief Justice of the Supreme Court of Appeal. However, confronting the racism, sexism, arrogance and indifference of the individual players who made the previous system workable and credible (if only in the eyes of the beneficiaries) is a more challenging proposition.

Dyzenhaus thoughtfully and systematically argues why the legal hearings were so important in confronting both the institutional underpinnings of the apartheid legal order, as well as individual accountability for its excesses. And he laments the failure of judges, particularly liberal judges, to adequately confront their roles in providing credibility to this system.[57] However, as a 
mechanism, a process of countless written submissions and three days of testimony, the legal hearings could not have adequately canvassed what ultimately would be necessary to exorcise the legal system of its ignominious past.

Dyzenhaus' strong objection to Judge Chaskalson's 'little to be gained from lamenting the past' position is surprising. [58] If one sees the TRC as a product of a difficult process of negotiation and compromise, then the central protagonists of the process, insiders in other words, may have a greater sense of the possibilities of particular strategies. The TRC was about pursuing truth and reconciliation, but it was ultimately a political compromise. Former Justice Minister Abdullah Omar, chief architect of the TRC, noted that in creating the TRC, 'we grappled with how to deal with our past as part of a total constitutional and political settlement for our country'.[59]

Dyzenhaus has done an estimable task of narrating and analysing the TRC legal hearings. This book is a valuable contribution to the continuous assessment both of the procedures and substance of the TRC, and whether the purpose set out by its creators will in the long run be fulfilled. The book also continues the perennial discussion of the relationship between law and justice.

PENNY ANDREWS[*]

[1] Kader Asmal, Louise Asmal and Ronald Roberts, Reconciliation through Truth: A Reckoning of Apartheid's Criminal Governance (2nd ed, 1997) 5.

[2] Constitution of the Republic of South Africa Act 1996 (South Africa) ('Constitution').

[3] Allister Sparks, Tomorrow Is Another Country: The Inside Story of South Africa's Negotiated Revolution (1995).

[4] See Karen Cavanaugh, 'Emerging South Africa: Human Rights Responses in the PostApartheid Era' (1997) 5 Cardozo Journal of International and Comparative Law 291.

[5] See Constitution ch 2. The Constitution provides, for example, for the establishment of the Human Rights Commission, the Gender Commission and the Public Protector: see Constitution ch 9 .

[6] The TRC was established by the Promotion of National Unity and Reconciliation Act 1995 (South Africa) s 2. See Piet Meiring, Chronicle of the Truth Commission (1999) 10.

[7] National Unity and Reconciliation, Epilogue to the Constitution.

[8] See Priscilla Hayner, 'Fifteen Truth Commissions - 1974 to 1994: A Comparative Study' (1994) 16 Human Rights Quarterly 597. 
[9] These institutional hearings were useful in many respects, not least because they highlighted the 'normalcy' and banality of institutionalised racism, its evolution into a system of unquestioned acceptability in all areas of South African life.

[10] For an interesting discussion of this question see Asmal, Asmal and Roberts, above $\mathrm{n} \underline{1}$.

[11] Promotion of National Unity and Reconciliation Act 1995 (South Africa) s 20.

[12] Azanian Peoples Organisation v The President of the Republic of South Africa (1996) 8 BCLR 1015 (Constitutional Court).

[13] For an interesting exploration of these matters, see Colin Bundy, 'Truth ... or Reconciliation' (1999) 14(4) Southern Africa Report 8.

[14] I use the term 'black' here to refer to Indians, 'Coloured' (mixed-race) people and Africans.

[15] See Jeremy Sarkin, 'The Trials and Tribulations of South Africa's Truth and Reconciliation Commission' (1996) 12 South African Journal on Human Rights 617.

[16] For the most poignant, interesting and insightful account of the Commission's proceedings, see Antjie Krog, Country of My Skull (1998).

[17] Stephen Friedman, 'Commission's Impartiality Under Fire', Business Day (Johannesburg, South Africa), 23 February 1998, 11 cited in Dyzenhaus, Judging the Judges, below n $\underline{18}, 11$.

[18] David Dyzenhaus, Judging the Judges, Judging Ourselves: Truth, Reconciliation and the Apartheid Legal Order (1998).

[19] Specifically, two questions were put to the actors in the legal system:

How was it that you implemented without protest, and often with zeal, laws that were so manifestly unjust? And how was it that when you had some discretion as to how to interpret or apply the law, you consistently decided in a way that assisted the government and the security forces?

Ibid 27.

[20] Dyzenhaus, Judging the Judges, above n $\underline{18}, 29$. The victims' hearings were supposed to allow victims to tell their stories, and in the process uncover the truth. Often the anguish of the victims' testimony led to open hostility, anger and frustration. See Timothy Ash, 'True Confessions' (1997) 44(12) New York Review of Books 33, 34.

[21] Dyzenhaus, Judging the Judges, above n $\underline{18}$, 29-30.

[22] See generally John Dugard, Human Rights and the South African Legal Order (1978). 
[23] Hayner, above $\mathrm{n} \underline{8}, 613-17,621-3,627-9$. For a detailed outline of the human rights struggle in Latin America, see Penny Lernoux, Cry of the People (1980).

[24] See Albie Sachs, Justice in South Africa (1973); see also C R M Dlamini, 'The Influence of Race on the Administration of Justice in South Africa' (1988) 4 South African Journal on Human Rights 37.

[25] This is not to suggest that the majority of black South Africans accepted the status quo. However, with black political opposition effectively stifled by the late 1950s through the imprisonment and banishment of its leaders, the system could be administered unfettered by widespread opposition.

[26] This point about beneficiaries of apartheid has been raised in the context of the victims' hearings, where the question of the responsibility and accountability of ordinary white South Africans, as beneficiaries of apartheid, was examined. The parameters of this paper do not allow for an elaboration of these questions, but they point to the acquiescence of white South Africans in this abhorrent system, a collusion made possible by the trappings of legality. For a discussion of these issues, see Krog, above n 16, 144-7.

[27] David Dyzenhaus, Hard Cases in Wicked Legal Systems: South African Law in the Perspective of Legal Philosophy (1991).

[28] Dyzenhaus recalls a particularly egregious episode on the part of the Johannesburg Bar Council, which moved swiftly to disbar a member, Bram Fischer, whom the Government had labelled a communist, and who was subsequently charged and imprisoned. It is a tale of great sadness because Fischer died of cancer after the prison authorities displayed gross indifference to his predicament. See Dyzenhaus, Judging the Judges, above n 18, 129-35.

[29] Only two law schools made submissions, and three Deans of law schools wrote letters to the TRC. Only two Attorneys-General and one prosecutor made written submissions.

[30] Arthur Chaskalson, 'Law in a Changing Society — The Past Ten Years: A Balance Sheet and Some Indicators for the Future' (1989) 5 South African Journal on Human Rights 293.

[31] Ibid 294; Dyzenhaus, Judging the Judges, above n $\underline{18}, 15$.

[32] Dyzenhaus, Judging the Judges, above n $\underline{18}, 16$.

[33] Ibid.

[34] Ibid 17-19.

[35] See David Hemson, 'Trade Unionism and the Struggle for Liberation in South Africa' in Martin Murray (ed), South African Capitalism and Black Political Opposition (1982) 685, 685737. 
[36] For a detailed account of the role played by lawyers during the struggle against apartheid, see Richard Abel, Politics by Other Means: Law in the Struggle against Apartheid, 1980-1994 (1995); see also Penelope Andrews, 'A Resource for Justice: South Africa's Legal Resources Centre’ (1995) 2 East Africa Journal of Peace and Human Rights 53.

[37] See Stephen Ellmann, 'Law and Legitimacy in South Africa' (1995) 20 Law and Social Inquiry 407.

[38] For a compelling account of the experiences of black lawyers in South Africa, see Kenneth Broun, Black Lawyers, White Courts (2000).

[39] See Stephen Ellmann, In a Time of Trouble: Law and Liberty in South Africa's State of Emergency (1992).

[40] Dyzenhaus, Judging the Judges, above n $\underline{18}$, ch 2.

[41] Because most judges did not make submissions (even though the submission of the former Chief Justice was made on behalf of the judiciary) it is unclear just how deep and widespread the nervousness was. By Dyzenhaus' own admission, the hearings often took the form of recriminations; it was arguable that this would not have been conducive to enhancing credibility, but rather the opposite.

[42] Only three days were allocated to the legal hearings.

[43] As it turns out, there were eight formal submissions from judges (including one joint submission from Judge A Chaskalson (President of the Constitutional Court), Judge I M Mahomed (Chief Justice of the Supreme Court of Appeal), Judge P Langa (Deputy President of Natal) (who also made an individual submission), Judge H J O Van Heerden (Deputy Chief Justice of the Supreme Court of Appeal) and Judge M M Corbett (former Chief Justice of the Supreme Court of Appeal)). For a list of submissions, see Dyzenhaus, Judging the Judges, above $\mathrm{n} \underline{18}, 187-9$.

[44] Ibid 22. It may have been useful for Dyzenhaus to consider alternatives to the TRC legal hearings as a way of confronting the legal past. It appears that Judge Chaskalson may not have been advocating amnesia, but rather attempting to build on the legal foundations despite the legal system's morally skewed past.

[45] Ibid 23.

[46] Raymond Wacks, 'Judges and Injustice' (1984) 101 South African Law Journal 266.

[47] John Dugard, 'Should Judges Resign? A Reply to Professor Wacks' (1984) 101 South African Law Journal 286.

[48] For an interesting discussion of this debate, and general issues about judges and democracy, see Hugh Corder (ed), Democracy and the Judiciary (1989). 
[49] Dyzenhaus refers to a judgment by the late Didcott J, a liberal judge in the old order, and a member of the Constitutional Court until his death, in which he carved out a requirement of justice when interpreting a statute notorious for its perpetual oppression of black South Africans: see Dyzenhaus, Judging the Judges, above n $\underline{18}$, 75-6.

[50] Ibid 26.

[51] See Martin Chanock, 'The South African Native Administration Act of 1927: Reflections on a Pathological Case of Legal Pluralism' in Oliver Mendelsohn and Upendra Baxi (eds), The Rights of Subordinated Peoples (1994) 295.

[52] Geoffrey Budlender, 'Incorporation and Exclusion: Recent Developments in Labour Law and Influx Control' (1985) 1 South African Journal on Human Rights 3.

[53] Robert Cover, Justice Accused: Antislavery and the Judicial Process (1975).

[54] Dyzenhaus, Judging the Judges, above n $\underline{18}, 34$.

[55] Ibid 35.

[56] See, eg, Sparks, above n $\underline{3}$.

[57] Dyzenhaus' level of opprobrium against liberal judges is surprising. The force of his argument against their acquiescence in the system, their inability as it were, to face their contradictions, points to the many compromises that South Africans made. Those included, for example, the decision to serve in the apartheid military machine. Yes, in that system choices were circumscribed severely, but people made them nonetheless. What then is important is to assess the motives for the compromises, a rather personal venture, and one not necessarily conducive to a public hearing.

[58] As Dyzenhaus notes, Judge Chaskalson is one of the foremost South African jurists, whose record on human rights and public interest is impeccable. He was also one of the chief legal advisors to the constitutional negotiations. That the disagreement occurs is not surprising, but since Judge Chaskalson is the ultimate insider, with a deep sense of what constitutes appropriate strategies, it is not too implausible to suggest that his perspective about coping with the past has been well thought out. And I am not suggesting that his position as an insider immunises him from criticism or disagreement, but rather that his perspective emanates from his deep involvement in the processes of transformation, and the choice between morality, legalism and politics, a perspective not always available to outside commentators.

[59] The Hon Abdullah Omar, Speech prepared for 'Collective Violence and Memory: Judgment, Reconciliation, Education', the Facing History and Ourselves: Twelfth Annual Human Rights and Justice Conference, Harvard University, Cambridge, Massachusetts, 10 April 1997 (emphasis added). 
[*] BA, LLB (Natal, South Africa), LLM (Columbia); Associate Professor, School of Law, City University of New York. 